\title{
Development of uracil-DNA-glycosylase-supplemented loop-mediated isothermal amplification coupled with nanogold probe (UDG-LAMP-AuNP) for specific detection of Pseudomonas aeruginosa
}

\author{
ORAPAN MANAJIT ${ }^{1,2}$, SIWAPORN LONGYANT $^{1,2}$, \\ PAISARN SITHIGORNGUL ${ }^{1,2}$ and PARIN CHAIVISUTHANGKURA ${ }^{1,2}$ \\ ${ }^{1}$ Department of Biology, Faculty of Science; ${ }^{2}$ Center of Excellence for Animal, Plant and Parasite Biotechnology, \\ Srinakharinwirot University, Bangkok 10110, Thailand
}

Received September 15, 2017; Accepted January 22, 2018

DOI: $10.3892 / \mathrm{mmr} .2018 .8557$

\begin{abstract}
Pseudomonas aeruginosa ( $P$. aeruginosa) is an important opportunistic pathogen that causes serious infections in humans, including keratitis in contact lens wearers. Therefore, establishing a rapid, specific and sensitive method for the identification of $P$. aeruginosa is imperative. In the present study, the uracil-DNA-glycosylase-supplemented loop-mediated isothermal amplification combined with nanogold labeled hybridization probe (UDG-LAMP-AuNP) was developed for the detection of $P$. aeruginosa. UDG-LAMP was performed to prevent carry over contamination and the LAMP reactions can be readily observed using the nanogold probe. A set of 4 primers and a hybridization probe were designed based on the ecf $X$ gene. The UDG-LAMP reactions were performed at $65^{\circ} \mathrm{C}$ for $60 \mathrm{~min}$ using the ratio of $40 \%$ deoxyuridine triphosphate to $60 \%$ deoxythymidine triphosphate. The detection of UDG-LAMP products using the nanogold labeled hybridization probe, which appeared as a red-purple color, was examined at $65^{\circ} \mathrm{C}$ for 5 min with $40 \mathrm{mM}$ $\mathrm{MgSO}_{4}$. The UDG-LAMP-AuNP demonstrated specificity to all tested isolates of $P$. aeruginosa without cross reaction to other bacteria. The sensitivity for the detection of pure culture was $1.6 \times 10^{3}$ colony-forming units (CFU) $\mathrm{ml}^{-1}$ or equivalent to $3 \mathrm{CFU}$ per reaction while that of polymerase chain reaction was $30 \mathrm{CFU}$ per reaction. The detection limit of spiked contact lenses was $1.1 \times 10^{3} \mathrm{CFU} \mathrm{ml} \mathrm{m}^{-1}$ or equivalent to $2 \mathrm{CFU}$ per reaction. In conclusion, the UDG-LAMP-AuNP assay was
\end{abstract}

Correspondence to: Dr Parin Chaivisuthangkura, Department of Biology, Faculty of Science, Srinakharinwirot University, 23 Sukhumvit, Bangkok 10110, Thailand

E-mail: parin@g.swu.ac.th

Key words: Pseudomonas aeruginosa, loop-mediated isothermal amplification, uracil-DNA-glycosylase, gold nanoparticle rapid, simple, specific and was effective for the identification of $P$. aeruginosa in contaminated samples.

\section{Introduction}

Pseudomonas aeruginosa is a gram-negative, rod-shaped, belonging to the family of Pseudomonadaceae. It can be found in many natural environments including warm and moist atmospheres containing very low levels of organic material (1). Therefore, P. aeruginosa can contaminate contact lens, cosmetic and several hospital niches, including taps, drains, water pipes, medical equipment and several other devices leading to nosocomial infections (2). This organism is an opportunistic pathogen that can cause serious infections including septicemia, pneumonia, endocarditis, otitis and keratitis (3). $P$. aeruginosa is an increasingly frequent organism found in humans with bacterial keratitis particularly among contact lens wearers (4). This organism can adhere on the surface of contact lens and form the biofilm, as a result, ability to grow is increasing and it is difficult to dispose. P. aeruginosa is an important cause of keratitis and may lead to permanent loss of vision if not treated promptly and appropriately (5). Therefore, the rapid and accurate method for determination of $P$.aeruginosa is required.

Identification of $P$. aeruginosa in the clinical laboratory is generally performed by growing the bacteria on nalidixic acid-cetrimide (NAC) agar or cetrimide agar, Pseudomonas $\mathrm{CN}$ selective agar $(\mathrm{PCN})$ and Pseudomonas isolation agar (PIA). Although this method is credible but the time required for performing is $24-72 \mathrm{~h}$, which is a long time and other Pseudomonas species may display similar growth that limit the identification of species (6). Using polymerase chain reaction (PCR) methods, which allow for more rapid identification of $P$. aeruginosa, have been shown to be highly specific and less time-consuming than classical method $(3,7,8)$ and PCR have also been reported $(9,10)$. However, the PCR based methods require expensive device and skilled personnel to avoid cross contamination between samples. 
A novel nucleic acid amplification method termed loopmediated isothermal amplification (LAMP) using a set of four oligonucleotide primers and the strand displacement enzyme for amplification of target gene at constant temperature ranging from 60 to $65^{\circ} \mathrm{C}$ was invented (11). LAMP method has been successfully used to detect various bacterial pathogens such as Vibrio vulnificus (12), Vibrio parahaemolyticus (13), and Salmonella spp. (14). In the case of P. aeruginosa detection, traditional LAMP methods based on various genes such as outer membrane lipoprotein I (opr I) gene (15), outer membrane lipoprotein L (opr L) gene (16), ecfX gene in bottled water samples (17), exoS and exoU of Type III Secretion System (18) were reported. In order to increase specificity, the visualization of LAMP product using a labelled-hybridization probe is an alternative method. The LAMP assay combined with DNA-labeled gold nanoparticles (AuNP) probe were established to detect various viral pathogens such as shrimp yellow head virus (YHV) (19), white spot syndrome virus (WSSV) (20), or identification of human DNA in forensic evidence (21). In this system, the DNA-AuNP probe aggregates with a color shift from red to blue or colorless at optimal salt concentration if there is no hybridization reaction (18). However, hybridization of the AuNP probe to a complementary target DNA prevents aggregation in salt environment and solution remained red.

Since LAMP method is highly sensitive for nucleic acid amplification; therefore, the assay is likely susceptible to carryover contamination. To overcome this problem, a one-pot, closed-vessel enzymatic assay that prevent carryover contamination during LAMP reaction was reported (22).This system used uracil-DNA-glycosylase (UDG) to digest uracilcontaining LAMP amplicons from previous reaction prior to performing LAMP amplification in the same tube. This system had been successfully used with traditional LAMP assay for detection of Salmonella Typhimurium (22). In the present study, a modified UDG-LAMP combined with colorimetric AuNP probe assay (UDG-LAMP-AuNP) for specific identification of $P$. aeruginosa based on ecf $X$ gene was developed. The specificity and sensitivity for detection of $P$. aeruginosa was also investigated.

\section{Materials and methods}

Bacterial isolates and DNA extraction. A total of 39 bacterial isolates including 16 isolates of $P$. aeruginos $a, 8$ isolates of Pseudomonas spp. and 15 isolates of other bacteria were used in the present study (Table I). The $16 \mathrm{~S}$ rRNA gene amplifications were performed to verify the bacterial identification as described in a previous report (23). The origins and sources of all 40 bacterial isolates tested were indicated in Table I. All bacterial isolates were grown for overnight at $37^{\circ} \mathrm{C}$ in trypticase soy agar (TSA). A single colony from TSA was picked and inoculated into trypticase soy broth (TSB) at $37^{\circ} \mathrm{C}$ for overnight.

DNA was extracted from bacteria cultured in TSB by using QIAamp DNA mini kit (Qiagen, Inc., Valencia, CA, USA) according to the manufacture's manual. The extracted DNA was stored at $-20^{\circ} \mathrm{C}$ until use and an isolate of $P$. aeruginosa (PA07) ATCC was used for the assay of optimization and sensitivity testing with pure culture.
General PCR. The DNA extracted from bacterial samples was used as a template for PCR amplification. The PCR amplification of ecf $\mathrm{X}$ gene was performed as described in previous reports (3). Briefly, the PCR was carried out with primers ECF 1 (ATGGATGAGCGCTTCCGT) and ECF 2 (TCATCC TTCGCCTCCCTG) for 35 cycles, each of which consisted of denaturation at $94^{\circ} \mathrm{C}$ for $45 \mathrm{sec}$, annealing at $58^{\circ} \mathrm{C}$ for $45 \mathrm{sec}$ and extension at $72^{\circ} \mathrm{C}$ for $30 \mathrm{sec}$. The PCR amplicon size was $528 \mathrm{bp}$. PCR products were separated by electrophoresis on $1 \%$ (w/v) agarose gel and visualized using a gel documentation system (Dynamica GelView Master).

Design of LAMP primers and probe for the LAMP assay. A set of four primers consisting of 2 outer primers (F3 and B3) and 2 inner primers (FIP and BIP) recognized six distinct regions on ecf X gene (GenBank, accession no. DQ 996559.1) of $P$. aeruginosa was designed using PrimerExplorer ver. 4 (http://primerexplorer.jp/elamp4.0.0/index.html). The FITC-labeled oligonucleotide probe was synthesized and labeled with a thiol group at 5'-end (Bio Basic Inc., Markham, Ontario, Canada). The sequences of primers and probe are shown in Table II.

Optimization of UDG-LAMP conditions. In order to prevent the carryover contamination of LAMP product, the UDG-LAMP reactions were performed as described by a previous study with some modification. The dTTP in a standard dNTP mix was partially replaced with dUTP and UDG was used to degrade uracil-labeled LAMP amplicons (22).

The UDG-LAMP assay was carried out in a total of $25 \mu \mathrm{l}$ reaction mixture consisted of $40 \mathrm{pmol}$ each of the inner primers (FIP and BIP), 5 pmol each of the outer primers (F3 and B3), $1.4 \mathrm{mM}$ each of dATP, dGTP, dCTP and dUTP: dTTP (different ratios at $100 \%$ dUTP; $80 \%$ dUTP $+20 \%$ dTTP; $60 \%$ dUTP + 40\% dTTP; $40 \%$ dUTP +60\% dTTP; $20 \%$ dUTP $+80 \%$ dTTP; and 100\% dTTP) (New England Biolabs, Inc., Ipswich, MA, USA), $5.0 \mathrm{mM}$ of $\mathrm{MgSO}_{4}, 0.8 \mathrm{M}$ Betaine (Sigma-Aldrich; Merck KGaA, Darmstadt, Germany), $8 \mathrm{U}$ of $B$ st 2.0 DNA polymerase (New England Biolabs), $5 \mathrm{U}$ of UDG (New England Biolabs), 1X of supplied buffer and DNA template. The reaction mixture was incubated at $37^{\circ} \mathrm{C}$ for $5 \mathrm{~min}$. and then further incubated at 60,63 and $65^{\circ} \mathrm{C}$ for $60 \mathrm{~min}$ to determine the optimal temperature. To establish the optimal time, the UDG-LAMP reaction was carried out at pre-determined temperature of $65^{\circ} \mathrm{C}$ for $30,45,60,75$ and $90 \mathrm{~min}$ and heated at $80^{\circ} \mathrm{C}$ for $10 \mathrm{~min}$ to terminate the reaction. The products were analyzed by $2 \%$ agarose gel electrophoresis and visualized using a gel documentation system (Dynamica GelView Master).

Preparation of ssDNA-labeled gold nanoparticles probe (AuNPs-probe). The AuNPs probe was prepared according to a previous report (21). Briefly, $4 \mathrm{ml}$ of colloidal AuNPs with diameter of $10 \mathrm{~nm}$ (Sigma-Aldrich; Merck KGaA) was added to $2.5 \mathrm{nmol}$ of the thiol-probe and incubated with shaking at $150 \mathrm{rpm}, 45^{\circ} \mathrm{C}$ for $16 \mathrm{~h}$. The following solutions consisted of $4 \mu \mathrm{l}$ of $10 \% \mathrm{SDS}, 400 \mu \mathrm{l}$ of $100 \mathrm{mM}$ phosphate buffer, $\mathrm{pH} 7.5$ $\left(0.02 \mathrm{M} \mathrm{NaH}_{2} \mathrm{PO}_{4} \cdot \mathrm{H}_{2} \mathrm{O}, 0.08 \mathrm{M} \mathrm{Na}_{2} \mathrm{HPO}_{4} \cdot 7 \mathrm{H}_{2} \mathrm{O}\right)$ and $200 \mu \mathrm{l}$ of $2 \mathrm{M} \mathrm{NaCl}$ were added to the mixture and incubated at $45^{\circ} \mathrm{C}$, $150 \mathrm{rpm}$ shaking for $48 \mathrm{~h}$. The AuNPs-probe was precipitated 
Table I. Bacterial isolates used in the present study.

DNA amplification

$\operatorname{ecf} X$

Bacterial isolates

Origin

LAMP

PCR

Source

A, Pseudomonas aeruginosa $(\mathrm{n}=16)$

P. aeruginosa (PA02)

$P$. aeruginosa (PA04)

$P$. aeruginosa (PA05)

P. aeruginosa (PA06)

P. aeruginosa (PA07)

P. aeruginosa (PA08)

$P$. aeruginosa (PA10)

P. aeruginosa (PA11)

P. aeruginosa (PA12)

P. aeruginosa (PA14)

P. aeruginosa (PA16)

P. aeruginosa (PA17)

P. aeruginosa (PA19)

P. aeruginosa (PA20)

$P$. aeruginosa (PA21)

P. aeruginosa (PA22)
Unknown

Urine

Sputum

Compost

Outer-ear infection

Animal room water bottle

Bacterial resistance testing of latex paint

Sputum

Blood culture

Pus

Intercostal Drainage

Cerebrospinal fluid

Heart blood

Endo tracheal

Unknown

Unknown
DMST

DMST

DMST

DMST

ATCC

ATCC

ATCC

DMST

DMST

TISTR

DMST

DMST

DMST

DMST

DMST

TISTR

B, Pseudomonas spp. $(\mathrm{n}=8)$

\begin{tabular}{|c|c|c|c|c|}
\hline P. japonica 1526 & Flower of Haliconia $s p$. & - & - & TISTR \\
\hline P.putida 23201 & Unknown & - & - & DMST \\
\hline P. fluorescens 358 & Unknown & - & - & TISTR \\
\hline P. olevorans 1097 & Epoxidizes terminal olefins & - & - & TISTR \\
\hline P. syringae 19310 & Syringa vulgaris, Great Britain & - & - & ATCC \\
\hline P. stutzeri 22487 & Blood culture & - & - & DMST \\
\hline P. boreopolis 33662 & Unknown & - & - & ATCC \\
\hline P. acidovorans & Unknown & - & - & Unknown \\
\hline
\end{tabular}

C, Other bacteria $(n=15)$

Escherichia coli 25922

Plesiomonas shigelloides 22107

Photobacterium damselae sub piscicida Vibrio ordalii VIB02

Vibrio anguillarum AVL01

Vibrio campbellii 21361

Vibrio alginolyticus 24047

Vibrio cholerae 22117

Vibrio shilonii 4907012

Vibrio harveyi 639

Salmonella Typhimurium 14029

Salmonella Enteritidis 7108

Staphylococcus aureus 25923

Aeromonas veronii 21255

Yersinia rukeri

Unknown
Rectal swab
Unknown
Unknown
Unknown
Unknown
Stool
Stool
Penaeus vannamei
Penaeus monodon
Unknown
Unknown
Unknown
Unknown
Unknown

ATCC

DMST

Unknown

DABU

GB

GB

DMST

DMST

SWU

CENTEX

ATCC

DMST

ATCC

DMST

DABU

ATCC, American Type Culture Collection, Rockville, Maryland, USA; CENTEX, Centex Shrimp, Faculty of Science, Mahidol University, Thailand; DABU, Department of Aquatic Science, Burapa University, Thailand; DMST, Department of Medical Science, Ministry of Public Health, Thailand; GB, Ghent University, Belgium; SWU, Department of Biology, Srinakharinwirot University, Thailand; TISTR, Thailand Institute of Scientific and Technological Research; PA/P. aeruginosa, Pseudomonas aeruginosa; PCR, polymerase chain reaction; LAMP, loop-mediated isothermal amplification. 
Table II. Primers and the probe for loop-mediated isothermal amplification designed from the ecfX gene of Pseudomonas aeruginosa.

Primer

Sequence (5'-3')

Forward outer primer (F3)

Backward outer primer (B3)

Forward inner primer (FIP)

Backward inner primer (BIP)

Thiol probe

\author{
TCCGTGGTTCCGTCTCG \\ AAGTTGCGGGCGATCTG \\ TGCCCAGGTGCTTGCGCATTTTCATGCCTATCAGGCGTTCC \\ GCCGACCTCGCCCAGGATATTTTGCTCGACCGATTGCCG \\ (SH-) $\mathrm{A}_{10}$ GGATACTTTCGACCAGTGGC
}

with centrifugation at $20,000 \times \mathrm{g}, 4^{\circ} \mathrm{C}$ for $30 \mathrm{~min}$. The pellet was washed twice with $700 \mu 1$ of solution containing $10 \mathrm{mM}$ phosphate buffer, $100 \mathrm{mM} \mathrm{NaCl}$, and $0.01 \%$ (w/v) SDS. Finally, the pellet was resuspended in $700 \mu \mathrm{l}$ of $10 \mathrm{mM}$ phosphate buffer, monitored for absorbance at $525 \mathrm{~nm}$ in the range of 0.3-0.4, stored at $4^{\circ} \mathrm{C}$ and protected from light.

Optimization of the AuNPs-probefor detection of UDG-LAMP products. To establish the optimal salt concentration for induction of free probe aggregation, $5 \mu \mathrm{l}$ of $\mathrm{MgSO}_{4}$ was added to the mixture (the total volume of $15 \mu \mathrm{l}$ ) to achieve the final concentration of 5, 10, 20, 40, 100 and $200 \mathrm{mM}$. The positive reaction (red-purple color) and negative reaction (blue-gray or colorless) were observed and recorded by naked eyes and by UV-visible analysis (Thermo Fisher Scientific, Inc., Waltham, MA, USA).

To optimize the hybridization temperature for detection of UDG-LAMP products, $2.5 \mathrm{nmol}$ of AuNPs-probe solution was added to the UDG-LAMP products in a 1:1 ratio at 57,62 and $65^{\circ} \mathrm{C}$ for $5 \mathrm{~min}$. The optimal hybridization time was investigated at 5, 10 and 20 min under pre-determined temperature $\left(65^{\circ} \mathrm{C}\right)$.

Specificity testing of PCR and UDG-LAMP-AuNPs assays. The specificity of UDG-LAMP-AuNPs and PCR based on ecf $X$ gene was performed to examine the 39 bacterial isolates including 16 isolates of $P$. aeruginos $a, 8$ isolates of Pseudomonas spp. and 15 isolates of other bacteria as shown in Table I. DNA templates isolated from bacterial cultures by QIAamp DNA mini kit (Qiagen) were used to evaluate the specificity test.

Sensitivity of UDG-LAMP-AuNPs and PCR assays in pure culture. The sensitivity of the UDG-LAMP-AuNPs assay for the detection of $P$. aeruginosa in pure culture was performed according to a previous study (24) with some modifications using known amounts of $P$. aeruginosa (PA 07). Briefly, bacterial cells from a single colony on TSA were inoculated into $4 \mathrm{ml}$ of trypticase soy broth (TSB; Difco) and incubated at $37^{\circ} \mathrm{C}$ for overnight. Approximately $40 \mu \mathrm{l}$ of TSB culture was added to a new $4 \mathrm{ml}$ of TSB and incubated at $37^{\circ} \mathrm{C}$ with shaking at $225 \mathrm{rpm}$ to mid-log phase (OD $600 \mathrm{~nm}=0.5-0.6$ ). Then, 10-fold serial dilutions of the cultures were prepared in phosphate-buffered saline solution (PBS).

To extract DNA from pure culture, $100 \mu \mathrm{l}$ of each dilution was transferred into a new microcentrifuge tube and centrifuged at $20,000 \mathrm{x} \mathrm{g}$ for $5 \mathrm{~min}$. Then, the supernatant was removed and the pellet was resuspended in $50 \mu 1$ of $25 \mathrm{mM} \mathrm{NaOH}$ and subsequently heated at $95^{\circ} \mathrm{C}$ for $5 \mathrm{~min}$. After neutralization with $4 \mu \mathrm{l}$ of $1 \mathrm{M}$ Tris- $\mathrm{HCl}$ buffer $(\mathrm{pH} 7.5)$, the suspension was centrifuged at $4^{\circ} \mathrm{C}, 20,000 \mathrm{x}$ g for $5 \mathrm{~min}$ and used as a template $(1 \mu \mathrm{l})$ with optimization condition for UDG-LAMP-AuNPs and PCR assays. The detection limit of UDG-LAMP-AuNPs detection methods was compared with that of PCR assay.

In parallel, to count the bacteria colony number, $100 \mu \mathrm{l}$ of each dilution was spread on TSA in duplicate and incubated at $37^{\circ} \mathrm{C}$ for overnight. The bacterial colonies were counted at the dilution yielding 30-300 colony-forming units (CFUs) and then the CFU ml-1 of bacterial suspension was calculated.

Sensitivities of UDG-LAMP-AuNPs and PCR with spiked contact lens. Contact lens samples (Pretty lens; VASSEN Co., Ltd., Pyeongtaek-si gyeonggido, Republic of Korea) were purchased at a store in Bangkok, Thailand. The contact lens samples were washed with $4 \mathrm{ml}$ of sterile PBS. The DNA template was prepared as described below and tested with PCR specific to ecf $X$ gene as indicated in the above section to confirm that they were negative for $P$. aeruginos $a$. The bacterial suspension and adherence of $P$. aeruginos $a$ to contact lens was employed according to a previous report (25) with some modifications using known amounts of $P$. aeruginosa (PA 07). Briefly, a single bacterial colony on TSA was inoculated into a $5 \mathrm{ml}$ of trypticase soy broth and incubated for overnight at $37^{\circ} \mathrm{C}$. Then, bacterial cells were collected by centrifugation at $2,000 \mathrm{x} \mathrm{g}$ for $10 \mathrm{~min}$ and the pellet was washed with sterile PBS twice before resuspended in PBS. The absorbance at $660 \mathrm{~nm}$ was adjusted to the range of 0.1 which is $\sim 10^{8} \mathrm{CFU}$ $\mathrm{ml}^{-1}$. Sterile contact lenses were transferred into $2 \mathrm{ml}$ of $10^{8} \mathrm{CFU} \mathrm{m} l^{-1}$ of PA07 and incubated at $37^{\circ} \mathrm{C}$ with shaking at $125 \mathrm{rpm}$ for $24 \mathrm{~h}$.

After $24 \mathrm{~h}$, the contact lenses were removed aseptically and washed gently with PBS to remove loosely attached microorganisms before transferred to $4 \mathrm{ml}$ sterile PBS and vortexed for $1 \mathrm{~min}$ to remove the adhered microorganisms. Then, 10-fold serial dilutions of the cultures were prepared in PBS. For DNA extraction, the $100 \mu \mathrm{l}$ of each dilution was centrifuged at 20,000 x g for $5 \mathrm{~min}$, the supernatant was removed and the pellet was resuspended in $50 \mu \mathrm{l}$ of $25 \mathrm{mM} \mathrm{NaOH}$ and subsequently heated at $95^{\circ} \mathrm{C}$ for $5 \mathrm{~min}$. After neutralization with $4 \mu \mathrm{l}$ of $1 \mathrm{M}$ Tris- $\mathrm{HCl}$ buffer ( $\mathrm{pH} 7.5$ ), the suspension was centrifuged at $4^{\circ} \mathrm{C}, 20,000 \times \mathrm{g}$ for $5 \mathrm{~min}$ and the supernatant was used as a template ( $1 \mu \mathrm{l})$ for UDG-LAMP-AuNPs and PCR assay. The sensitivity of UDG-LAMP-AuNPs was compared 
A

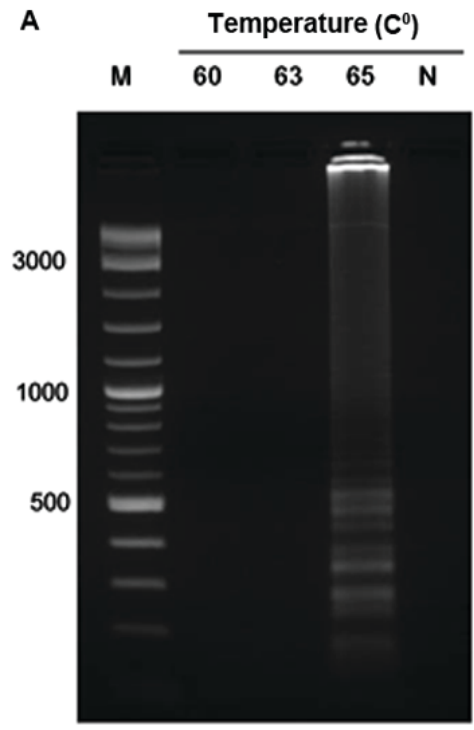

B

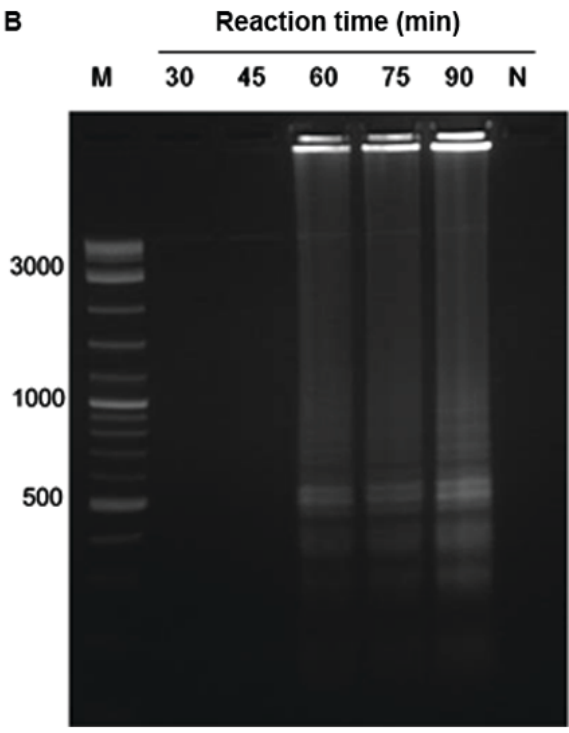

Figure 1. Determination of loop-mediated isothermal amplification conditions at different temperatures and time. (A) Various temperatures, as indicated on top of the gel, were tested for $60 \mathrm{~min}$, and (B) various reaction times, as indicated, were performed at $65^{\circ} \mathrm{C}$, using DNA extracted from the Pseudomonas aeruginosa 07 bacterial isolate. Lane $\mathrm{N}$, negative control (no DNA template); lane $\mathrm{M}$, molecular weight marker.

with that of PCR assay. In parallel, the bacterial colonies were counted as described above.

Statistical analysis. The results were analysed using the descriptive statistics tests of SPSS version 23.0 software (IBM Corp., Armonk, NY, USA). Data are presented as the mean \pm standard deviation of three independent experiments.

\section{Results}

Optimization of the temperature, reaction time and ratio of dUTP to dTTP for Pseudomonas aeruginosa detection by UDG-LAMP. To determine the optimal conditions for UDG-LAMP assay, various temperatures for the UDG-LAMP assay were conducted at 60,63 and $65^{\circ} \mathrm{C}$ for $60 \mathrm{~min}$. The ladder-like pattern characteristic of LAMP reaction was only observed at $65^{\circ} \mathrm{C}$ tested temperature; therefore, the temperature at $65^{\circ} \mathrm{C}$ was chosen for the subsequent UDG-LAMP assays (Fig. 1A).

To determine the optimal time for UDG-LAMP assay, the reaction was conducted at $65^{\circ} \mathrm{C}$ for $30,45,60,75$ and $90 \mathrm{~min}$. The LAMP amplicons could be clearly observed at 60, 75 and $90 \mathrm{~min}$ but no amplification was detected at 30 and $45 \mathrm{~min}$. Therefore, the reaction time at $60 \mathrm{~min}$ was chosen as optimal time for the UDG-LAMP assay to minimize the reaction time (Fig. 1B).

The LAMP reaction using Bst 2.0 DNA polymerase was well progressed using dUTP in place of dTTP; however, the concentration of dUTP affected the visible of ladder-like pattern characteristic on agarose gel. When dTTP was totally replaced with dUTP, the UDG-LAMP reaction produced no ladder-like pattern (Fig. 2, lane 1). Therefore, the ratio between dUTP to dTTP was varied from $80 \%$ dUTP $+20 \%$ dTTP; $60 \%$ dUTP + 40\% dTTP; $40 \%$ dUTP + 60\% dTTP; $20 \%$ dUTP $+80 \%$ dTTP; and 100\% dTTP. The ladder-like pattern was observed at the ratios of $60 \%$ dUTP $+40 \%$ dTTP; $40 \%$ dUTP+60\% dTTP; $20 \%$ dUTP + $80 \%$ dTTP; and $100 \%$

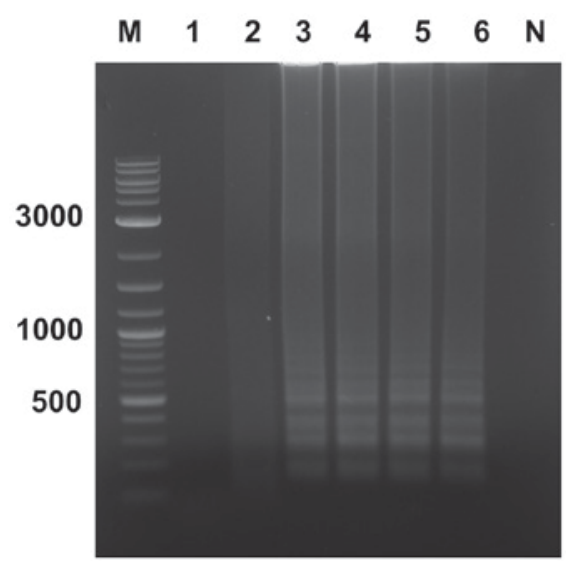

Figure 2. Optimization of dUTP to dTTP for loop-mediated isothermal amplification. The ratios of dUTP to dTTP were as follows: Lane 1, 100\% dUTP; lane 2, $80 \%$ dUTP + 20\% dTTP; lane 3, 60\% dUTP + 40\% dTTP; lane 4, 40\% dUTP+60\% dTTP; lane 5, 20\% dUTP+80\% dTTP; and lane 6, $100 \%$ dTTP. Lane M, molecular weight marker; lane N, negative control (no DNA template); dUTP, deoxyuridine triphosphate; dTTP, deoxythymidine triphosphate.

dTTP (Fig. 2). Therefore, the ratio of $40 \%$ dUTP to $60 \%$ dTTP was chosen for the subsequent UDG-LAMP assays to study the specificity and sensitivity.

Optimization of the AuNPs-probe for detection of UDG-LAMP products. To study the effect of salt concentration $\left(\mathrm{MgSO}_{4}\right)$, the UDG-LAMP product were hybridized to AuNPs probe under various concentrations of $\mathrm{MgSO}_{4}$ including 5, 10, 20, 40, 100 and $200 \mathrm{mM}$. The results showed that $40 \mathrm{mM} \mathrm{MgSO}_{4}$ yielded the clear difference between positive sample (red-purple) and negative control (blue-gray or colorless) (Fig. 3A and B). These results were corresponded to LAMP reactions followed by UV-visible analysis (Fig. 3C and D) and the absorbance at $525 \mathrm{~nm}$ clearly confirmed that results (Fig. 3E). Therefore, $40 \mathrm{mM} \mathrm{MgSO}_{4}$ was used for all subsequent assays. 

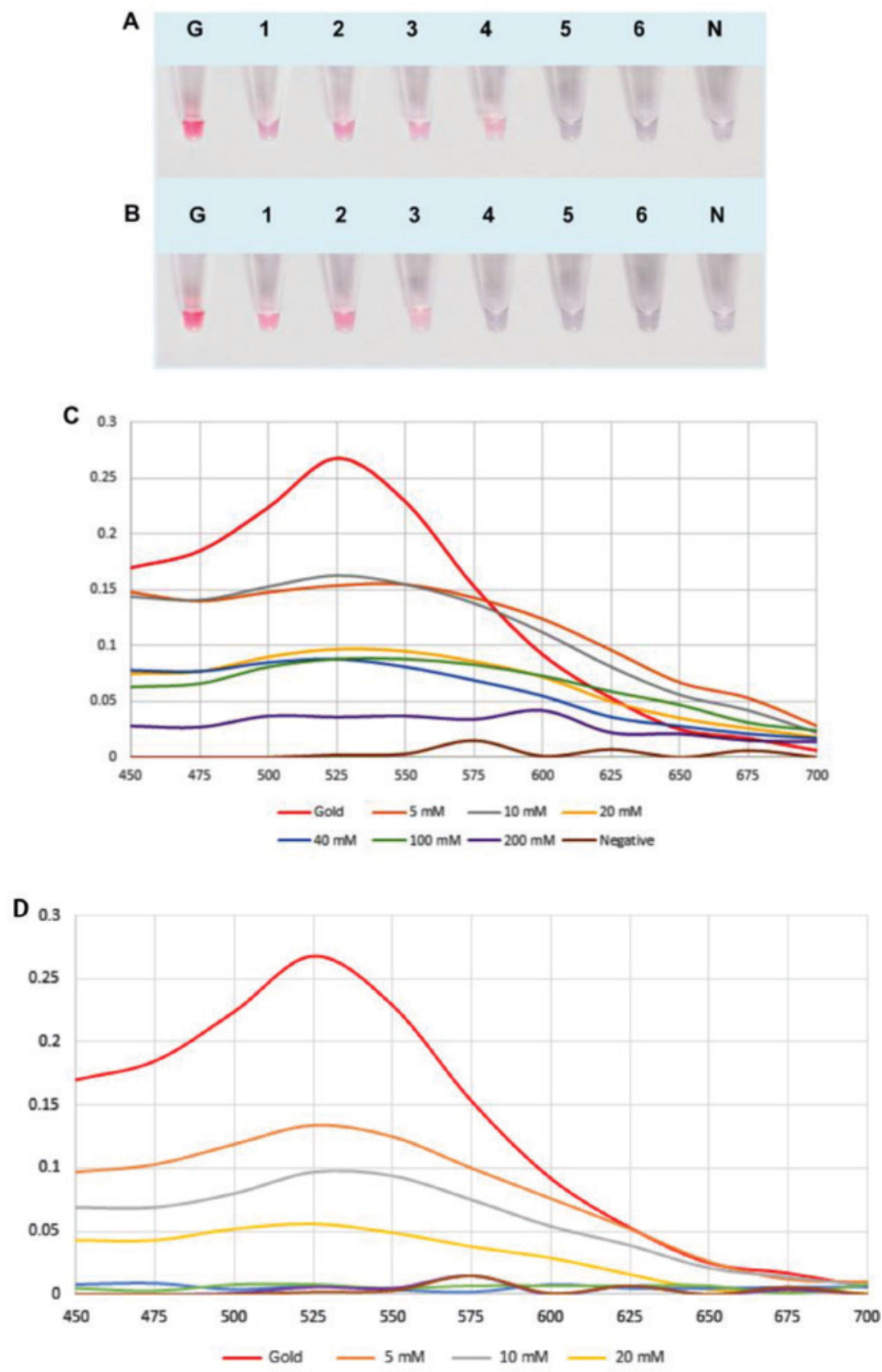

E

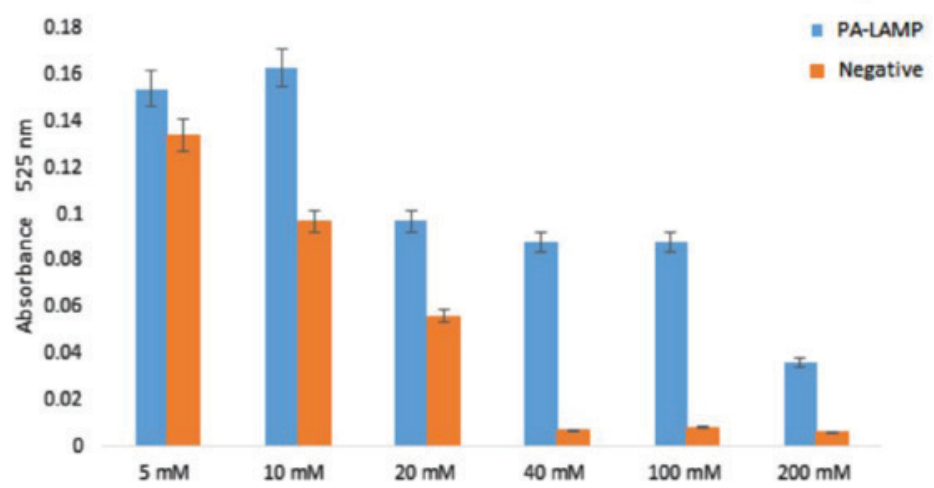

Figure 3. Optimization of the $\mathrm{MgSO}_{4}$ concentration for UDG-LAMP-AuNPs. (A) Various concentrations of $\mathrm{MgSO}_{4}$ were added with the AuNPs probe to $P$. aeruginosa UDG-LAMP products and (B) non- $P$. aeruginosa UDG-LAMP products (negative control). Hybridization was performed at $65^{\circ} \mathrm{C}$ for 5 min. Lane G, AuNPs probe only (without salt solution); lane 1-6, $\mathrm{MgSO}_{4}$ concentration at 5, 10, 20, 40, 100 and $200 \mathrm{mM}$, respectively; lane $\mathrm{N}$, negative control (no DNA template). Absorption spectra of the colloidal AuNP probe in the presence of (C) P. aeruginosa UDG-LAMP products and (D) non-P. aeruginosa UDG-LAMP products under various concentrations of $\mathrm{MgSO}_{4}$. (E) Absorption of UV-visible spectrophotometer at the wavelength of $525 \mathrm{~nm}$. Blue bar indicates positive samples and the orange bar indicates negative samples. LAMP, loop-mediated isothermal amplification; UDG-LAMP-AuNPs, uracil-DNAglycosylase-supplemented LAMP coupled with nanogold probe; AuNPs, gold nanoparticles; PA/P. aeruginosa, Pseudomonas aeruginosa. 


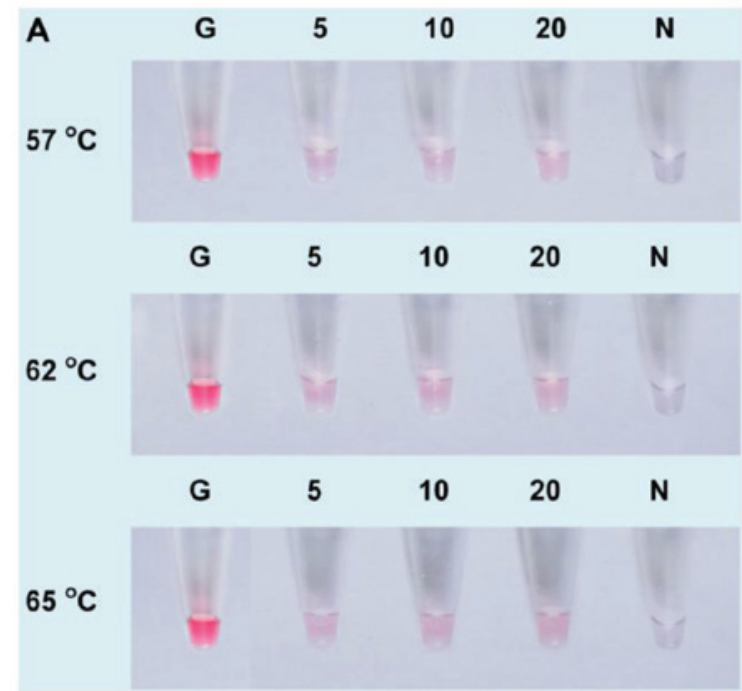

B

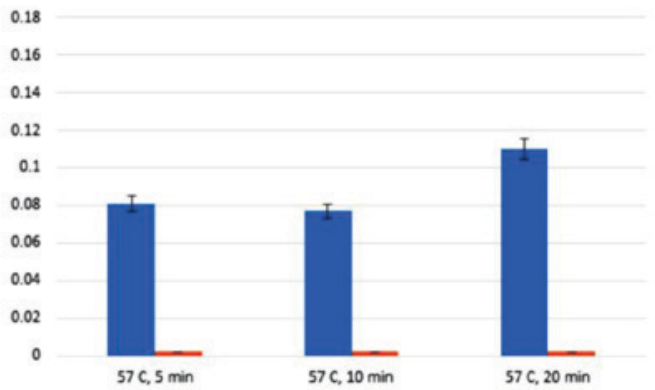

C

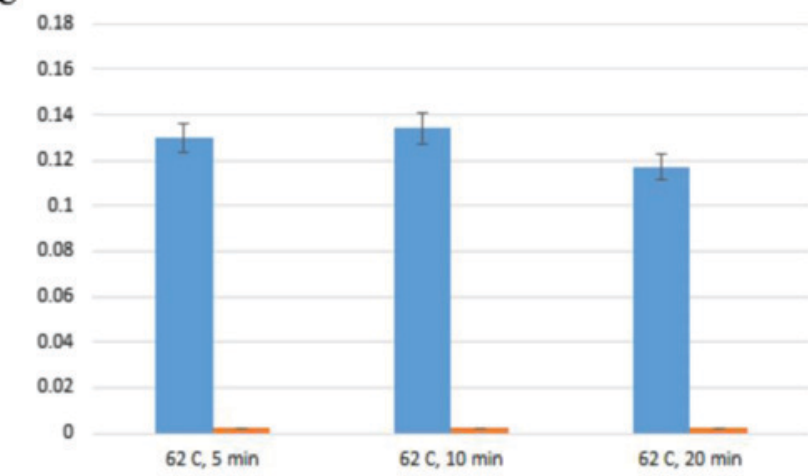

D 0.18

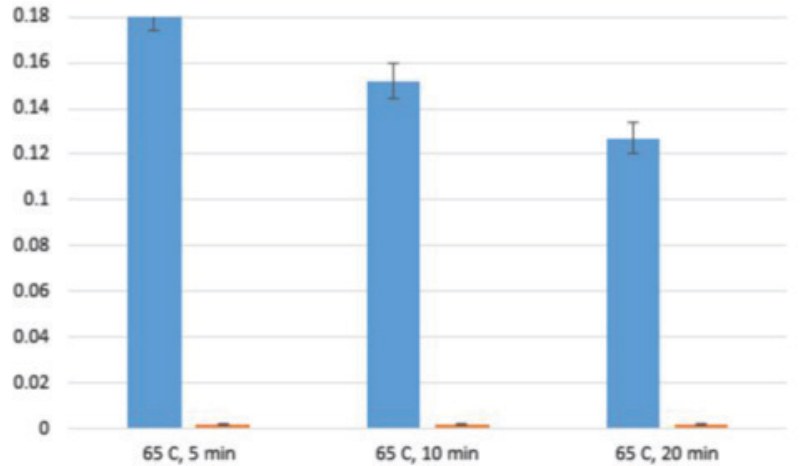

Figure 4. (A) Optimization of hybridization temperatures and durations for the detection of UDG-LAMP products at 57,62 and $65^{\circ} \mathrm{C}$ for 5,10 and $20 \mathrm{~min}$, respectively. Lane G, AuNPs probe only (without salt solution); lane N, negative control (no DNA template). Absorption of ultraviolet-visible spectrophotometer at a wavelength of $525 \mathrm{~nm}$ for the detection of UDG-LAMP products using hybridization time at 5,10 and $20 \mathrm{~min}$ for (B) $57^{\circ} \mathrm{C}$, (C) $62^{\circ} \mathrm{C}$ and (D) $65^{\circ} \mathrm{C}$. Blue bars indicate positive sample and orange bars indicate negative samples. UDG-LAMP, uracil-DNA-glycosylase-supplemented loop-mediated isothermal amplification; AuNPs, gold nanoparticles.

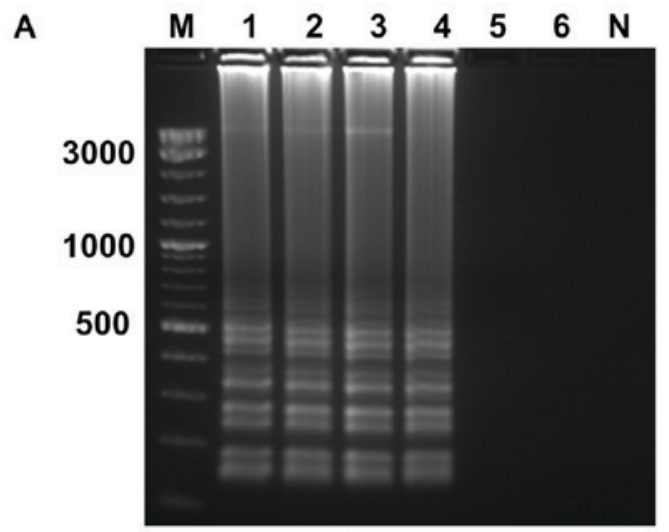

B
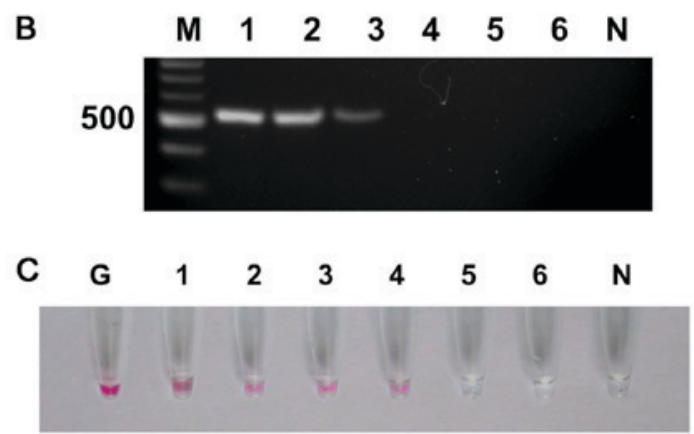

Figure 5. Sensitivity testing for $P$. aeruginosa pure culture detection by (A) UDG-LAMP, (B) polymerase chain reaction and (C) UDG-LAMPAuNP. Lanes 1-6 represent the 10-fold serial dilution of $P$. aeruginosa from $1.6 \times 10^{6} \mathrm{CFU} \mathrm{ml}^{-1}$ to $1.6 \times 10^{1} \mathrm{CFU} \mathrm{ml}^{-1}$. Lane $\mathrm{M}$, molecular weight DNA marker; lane $\mathrm{N}$, negative control; lane $\mathrm{G}$, gold nanoparticle probe only; P. aeruginosa, Pseudomonas aeruginosa; CFU, colony-forming units; UDG, uracil-DNA-glycosylase; LAMP, loop-mediated isothermal amplification; AuNPs, gold nanoparticles.

To determine the optimal temperature and time for hybridization between AuNPs probe and UDG-LAMP product, the hybridization was conducted at 57,62 and $65^{\circ} \mathrm{C}$ for 5,10 , and $20 \mathrm{~min}$ at each temperature. The color reactions demonstrated similar results in all ranges of the tested temperature and time (Fig. 4A). However, the UV-visible analysis revealed that the hybridization at $65^{\circ} \mathrm{C}$ for 5 min yielded the highest absorbance at $525 \mathrm{~nm}$ (Fig. 4D). Therefore, the hybridization performed at the temperature of $65^{\circ} \mathrm{C}$ for 5 min was chosen for the subsequent reactions.

Specificity of the UDG-LAMP-AuNPs and PCR assays. The specific testing demonstrated that UDG-LAMP-AuNPs and PCR specific to ecf $X$ gene revealed positive results to all tested isolates of $P$. aeruginosa. While 8 other Pseudomonas species and all non-Pseudomonas bacteria yielded negative results (Table I).

Detection limit of UDG-LAMP-AuNPs and PCR assays with pure culture. To determine the sensitivity of UDG-LAMPAuNPs and PCR assays for detection of P.aeruginosa (PA07), the stock solution of bacterial culture $\left(1.6 \times 10^{8} \mathrm{CFU} \mathrm{ml^{-1 }}\right)$ was diluted in 10-fold serial dilution and DNA extracted from each dilution was used in the UDG-LAMP-AuNPs and PCR assays. The UDG-LAMP and UDG-LAMP-AuNPs assay exhibited the positive result at $1.6 \times 10^{3} \mathrm{CFU} \mathrm{ml}^{-1}$ or equivalent to $\sim 3$ CFU per reaction (Fig. 5A and C), whereas, the PCR assay 
A

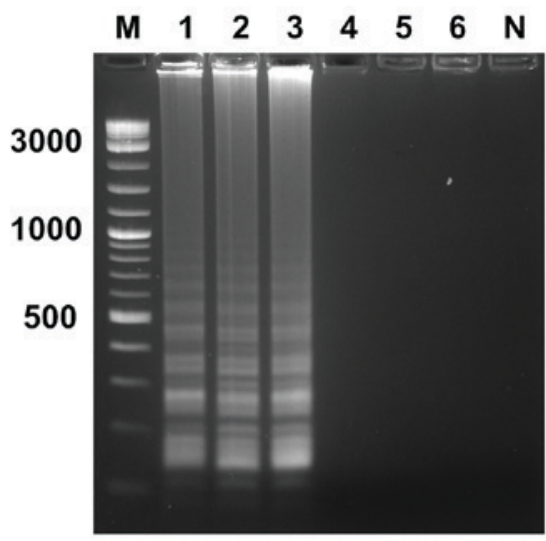

B

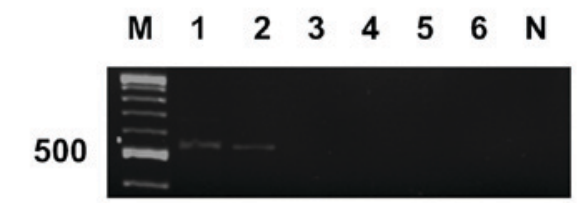

C

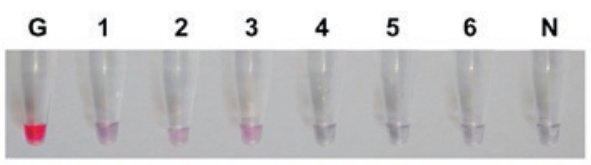

Figure 6. Sensitivity testing for $P$. aeruginos $a$ detection in contact lens samples by (A) UDG-LAMP, (B) polymerase chain reaction and (C) UDG-LAMPAuNP. Lanes 1-6 represent the 10-fold serial dilution of P. aeruginosa from $1.1 \times 10^{5} \mathrm{CFU} \mathrm{ml}{ }^{-1}$ to $1.1 \mathrm{CFU} \mathrm{ml}^{-1}$. Lane $\mathrm{M}$, molecular weight DNA marker; lane $\mathrm{N}$, negative control; lane $\mathrm{G}$, gold nanoparticle probe only; P. aeruginosa Pseudomonas aeruginosa; CFU, colony-forming units; UDG, uracil-DNAglycosylase; LAMP, loop-mediated isothermal amplification; AuNPs, gold nanoparticles.

showed the detection limit at $1.6 \times 10^{4} \mathrm{CFU}$ ml-1 or equivalent to $30 \mathrm{CFU}$ per reaction (Fig. $5 \mathrm{~B}$ ).

Sensitivity of UDG-LAMP-AuNPs and PCR assay with spiked contact lens samples. The detection limit of UDG-LAMP-AuNPs and PCR assays for PA07 spiked into contact lenses was examined. After removal of loosely attached bacteria, the determined number of bacteria in washed solution was $1.1 \times 10^{6} \mathrm{CFU} \mathrm{ml}{ }^{-1}$. After 10 -fold serial dilutions of washed solution was performed, the total DNA extracted from each dilution was used to investigate the detection limit. The results showed the sensitivity of UDG-LAMP and UDG-LAMP-AuNPs at $1.1 \times 10^{3} \mathrm{CFU} \mathrm{ml}^{-1}$ or equivalent to $2 \mathrm{CFU}$ per reaction (Fig. 6A and C). Whereas, the PCR assay showed detection limit at $1.1 \times 10^{4} \mathrm{CFU} \mathrm{ml} l^{-1}$ or equivalent to 20 CFU per reaction (Fig. 6B).

\section{Discussion}

P. aeruginosa is one of the most important pathogens causing human infections such as pneumonia, bacteremia, urinary tract infections and keratitis $(26,27)$. Microbial keratitis is a serious complication of contact lens wear and P.aeruginosa is a common causative agents associated with infectious keratitis reported in many countries (28). In order to manage patient infection, a rapid and specific detection method is required to differentiate keratitis caused by P. aeruginosa from other microorganism infections.
In the present study, a UDG-LAMP-AuNP method targeting to the ecf $X$ gene of $P$. aeruginosa was successfully developed. The optimum temperature and time for UDG-LAMP reaction were $65^{\circ} \mathrm{C}$ and $60 \mathrm{~min}$, respectively. Upon hybridization with nanogold labeled probe and salt addition, the positive reaction (red-purple color) of UDG-LAMP products could be observed within 5-10 min. This is more rapid than the PCR method and more suitable for small laboratory since the sophisticated equipment is not required. The LAMP assay is highly sensitive for DNA amplification; therefore, it is prone to carryover contamination. In our study, the UDG was effectively used to digest the uracil incorporated amplicons in a one-tube, closed vessel reaction. This UDG-LAMP strategy was successfully employed with Salmonella Typhimurium (22) and multiplex LAMP for simultaneous detection of white spot syndrome virus (WSSV) and infectious hypodermal and hematopoietic necrosis virus (IHHNV) in shrimp (29). In the present study, the optimum ratio of $40 \%$ dUTP to $60 \%$ dTTP was used. This ratio was in agreement with that of previous reports for detection of Salmonella Typhimurium (the ratio of 1:1) (22) and WSSV-IHHNV (the ratio of 5/8) (29).

The gold nanoparticle can interact with disulfide modified DNA probe and the ability to change color (from red to blue) on self-assembly is due to aggregation at an optimal salt concentration. In our study, under the low-salt concentration (5 to $10 \mathrm{mM} \mathrm{MgSO}_{4}$ solution), the AuNP probes were still stabilized in both control samples and the samples containing P. aeruginosa. However, at $40 \mathrm{mM} \mathrm{MgSO}$ the aggregation of AuNP probes in the control sample was clearly observed (blue-gray or colorless) and could be distinguishable from positive sample containing $P$. aeruginosa (red color). This result was in good agreement with previous report on specific detection of WSSV (20).

Previous studies on detection of $P$. aeruginosa showed that the false-negative results could be obtained from PCR assays targeting to the tox $A$ and $\operatorname{alg} D$ genes due to the highly polymorphic characteristic and sequence variation of $P$. aeruginosa $(3,30)$. However, the PCR assay targeting to ecfX for specific detection of $P$. aeruginosa has been reported (3). In our UDG-LAMP-AuNPs assay, four specific LAMP primers and DNA probe targeting to $e c f X$ gene of $P$. aeruginosa were designed and employed to ensure high specificity of nucleic acid amplification (3). Positive results were obtained for all tested $P$. aeruginosa isolates without cross-reaction to other bacterial species, demonstrating that these LAMP primers and DNA probe were specific for identification of P. aeruginosa.

In the present study, the sensitivity of UDG-LAMP-AuNPs assay in pure culture was $1.6 \times 10^{3} \mathrm{CFU} \mathrm{ml}{ }^{-1}$ or equivalent to $3 \mathrm{CFU}$ per reaction, 10 times more sensitive than that of PCR. The detection limit of UDG-LAMP-AuNPs at 3 CFU per reaction was more sensitive than traditional LAMP method for detection of $P$. aeruginosa based on oprI gene (10 CFU per reaction) (15).

In the case of artificially inoculated contact lenses, the detection limit of UDG-LAMP-AuNPs was $1.1 \times 10^{3} \mathrm{CFU} \mathrm{ml}^{-1}$ or equivalent to $2 \mathrm{CFU}$ per reaction, 10 times more sensitive than that of PCR assay $\left(1.1 \times 10^{4} \mathrm{CFU} \mathrm{ml^{-1 }}\right.$ or equivalent to $20 \mathrm{CFU}$ per reaction). The sensitivity of UDG-LAMP-AuNPs 
in both pure culture and spiked contact lenses were more sensitive than that of the conventional PCR assay. These results agreed with previous studies that demonstrate a better sensitivity of LAMP compared to that of PCR $(13,15,16,31)$. The detection limit of UDG-LAMP-AuNPs for spiked contact lenses at $2 \mathrm{CFU}$ per reaction was comparable to that of colorimetric LAMP detection of $P$. aeruginosa inoculated in mouse feces at 3.25 CFU per reaction (16) and LAMP assay for direct detection of $P$. aeruginosa from equine genital swabs at 11 DNA copies per reaction (32).

Recently, a microchip electrical sensing for detection of $P$. aeruginosa was developed. The detection limit of spiked eye wash samples at $10 \mathrm{CFU} \mathrm{ml}{ }^{-1}$ was reported (33). Another study based on magnetic relaxation switch (MRSw) aptasensor for detection of $P$. aeruginosa with the sensitivity of $50 \mathrm{CFU} \mathrm{ml}{ }^{-1}$ was also reported (34). In our study, an inferior detection limit of $1.1 \times 10^{3} \mathrm{CFU}$ per ml was obtained. However, the UDG-LAMP-AuNPs reaction could be performed with simple and inexpensive heating block while the MRSw method required a large size and high cost of magnetic relaxation scanners which is improper for field study.

In conclusion, the first UDG-LAMP-AuNPs method for detection of $P$. aeruginosa based on ecfX gene was successfully established. The assay demonstrated high specificity and high sensitivity of $\sim 3$ CFU per reaction with pure culture and 2 CFU per reaction with spiked contact lens samples. The developed UDG-LAMP-AuNPs assay is a sensitive, simple, rapid and valuable tool for specific diagnosis of $P$. aeruginosa in contaminated biological samples.

\section{Acknowledgements}

The present study was supported by the Higher Education Research Promotion, Office of the Higher Education Commission, Thailand. The authors are also indebted to all of the institutes listed in Table I for providing the bacteria used in the present study.

\section{References}

1. van der Kooij D, Oranje JP and Hijnen WA: Growth of Pseudomonas aeruginosa in tap water in relation to utilization of substrates at concentrations of a few micrograms per liter. Appl Environ Microbiol 44: 1086-1095, 1982.

2. Romling U, Kader A, Sriramulu DD, Simm R and Kronvall G: Worldwide distribution of Pseudomonas aeruginosa clone C strains in the aquatic environment and cystic fibrosis patients. Environ Microbiol 7: 1029-1038, 2005.

3. Lavenir R, Jocktane D, Laurent F, Nazaret S and Cournoyer B: Improved reliability of Pseudomonas aeruginosa PCR detection by the use of the species-specific ecf $X$ gene target. J Microbiol Methods 70: 20-29, 2007.

4. Onlen Y, Tamer C, Oksuz H, Duran N, Altug ME and Yakan S: Comparative trial of different anti-bacterial combinations with propolis and ciprofloxacin on Pseudomonas keratitis in rabbits. Microbiol Res 162: 62-68, 2007.

5. McLaughlin-Borlace L, Stapleton F, Matheson M and Dart JK: Bacterial biofilm on contact lenses and lens storage cases in wearers with microbial keratitis. J Appl Microbiol 84: 827-838, 1998.

6. Weiser R, Donoghue D, Weightman A and Mahenthiralingam E: Evaluation of five selective media for the detection of Pseudomonas aeruginosa using a strain panel from clinical, environmental and industrial sources. J Microbiol Methods 99: $8-14,2014$.
7. Jimenez L, Smalls S and Ignar R: Use of PCR analysis for detecting low levels of bacteria and mold contamination in pharmaceutical sample. J Microbiol Methods 41: 259-265, 2000.

8. Deschaght P, Van daele S, De Baets F and Vaneechoutte M: PCR and the detection of Pseudomonas aeruginosa in respiratory samples of CF patient. A literature review. J Cyst Fibros 10: 293-297, 2011.

9. Anuj SN, Whiley DM, Kidd TJ, Bell SC, Wainwright CE, Nissen MD and Sloots TP: Identification of Pseudomonas aeruginosa by a duplex real-time polymerase chain reaction assay targeting the ecfX and $g y r B$ genes. Diagn Microbiol infect Dis 63: 127-131, 2009.

10. McCulloch E, Lucas C, Ramage G and Williams C: Improved early diagnosis of Pseudomonas aeruginosa by real-time PCR to prevent chronic colonization in a pediatric cystic fibrosis population. J Cyst Fibros 10: 21-24, 2011.

11. Notomi T, Okayama H, Masubuchi H, Yonekawa T, Watanabe K, Amino $\mathrm{N}$ and Hase T: Loop-mediated isothermal amplification of DNA. Nucleic Acids Res 28: e63, 2000.

12. Surasilp T, Longyant S, Rukpratanporn S, Sridulyakul P, Sithigorngul $\mathrm{P}$ and Chaivisuthangkura P: Rapid and sensitive detection of Vibrio vulnificus by loop-mediated isothermal amplification combined with lateral flow dipstick targeted to rpoS gene. Mol Cell Probes 25: 158-163, 2011.

13. Prompamorn P, Sithigorngul P, Rukpratanporn S, Longyant S, Sridulyakul P and Chaivisuthangkura P: The development of loop-mediated isothermal amplification combined with a lateral flow dipstick for detection of Vibrio parahaemolyticus. Lett Appl Microbiol 52: 344-351, 2011.

14. Li J, Zhai L, Bie X, Lu Z, Kong X, Yu Q, Lv F, Zhang C and Zhao $\mathrm{H}$ : A novel visual loop-mediated isothermal amplification assay targeting gene 62181533 for the detection of Salmonella spp. in foods. Food control 60: 230-236, 2016.

15. Zhao X, Wang L, Li Y, Xu Z, Li L, He X,Liu Y, Wang J and Yang L: Development and application of a loop-mediated isothermal amplification method on rapid detection of Pseudomonas aeruginosa strains. World J Microbiol Biotechnol 27: 181-184, 2011.

16. Goto M, Shimada K, Sato A, Takahashi E, Fukasawa T, Takahashi T, Ohka S, Taniguchi T, Honda E, Nomoto A, et al: Rapid detection of Pseudomonas aeruginosa in mouse feces by colorimetric loop-mediated isothermal amplification. J Microbiol Methods 81: 247-252, 2010.

17. Zhang S, Xu X, Wu Q and Zhang J: Rapid and sensitive detection of Pseudomonas aeruginosa in bottled water by loop-mediated isothermal amplification. Eur Food Res Technol 236: 209-215, 2013.

18. Shi H, Chen Z and Kan J: Development of loop-mediated isothermal amplification assays for genotyping of Type III Secretion System in Pseudomonas aeruginosa. Lett Appl Microbiol 61: 361-366, 2015.

19. Jaroenram W, Arunrut N and Kiatpathomchai W: Rapid and sensitive detection of shrimp yellow head virus using loop-mediated isothermal amplification and a colorogenic nanogold hybridization probe. J Virol Methods 186: 36-42, 2012.

20. Seetang-Nun Y, Jaroenram W, Sriurairatana S, Suebsing R and Kiatpathomchai W: Visual detection of white spot syndrome virus using DNA-functionalized gold nanoparticles as probes combined with loop-mediated isothermal amplification. Mol Cell Probes 27: 71-79, 2013.

21. Watthanapanpituck K, Kiatpathomchai W, Chu E and Panvisavas N: Identification of human DNA in forensic evidence by loop-mediated isothermal amplification combined with a colorimetric gold amplification combined with a colorimetric gold nanoparticle hybridization probe. Int J Legal Med 128: 923-931, 2014.

22. Hsieh K, Mage PL, Csordas AT, Eisenstein M and Soh HT: Simultaneous elimination of carryover contamination and detection of DNA with uracil-DNA-glycosylase-supplemented loop mediated isothermal amplification (UDG-LAMP). Chem Commun 50: 3747-3749, 2014.

23. Weisburg WG, Barns SM, Pelletier DA and Lane DJ: 16S ribosomal DNA amplification for phylogenic study. J Bacteriol 173: 697-703, 1991.

24. Yamazaki W, Seto K, Taguchi M, Ishibashi M and Inoue K: Sensitive and rapid detection of cholera toxin producing Vibrio cholerae using a loop-mediated isothermal amplification. BMC Microbiol 8: 94, 2008.

25. Chan KY, Cho P and Boost M: Microbial adherence to cosmetic contact lenses. Cont Lens Anterior Eye 37: 267-272, 2014. 
26. Jarvis WR and Martone WJ: Predominant pathogens in hospital infections. J Antimicrob Chemother 29 (Suppl A): S19-S24, 1992.

27. Schwartz T, Volkmann H, Kirchen S, Kohnen W, Schön-Hölz K, Jansen B and Obst U: Real-time PCR detection of Pseudomonas aeruginosa in clinical and municipal wastewater and genotyping of the ciprofloxacin-resistant isolates. FEMS Microbiol Ecol 57: 158-167, 2006

28. Willcox MD: Management and treatment of contact lens-related Pseudomonas keratitis. Clin Ophthalmol 6: 919-924, 2012.

29. He L and Xu HS: Development of a multiplex loop-mediated isothermal amplification (mLAMP) method for the simultaneous detection of white spot syndrome virus and infectious hypodermal and hematopoietic necrosis virus in penaeid shrimp. Aquaculture 311: 94-99, 2011.

30. Qin X, Emerson J, Stapp J, Stapp L, Abe P and Burns JL: Use of real-time PCR with multiple targets to identify Pseudomonas aeruginosa and other nonfermenting gram-negative bacilli from patients with cystic fibrosis. J Clin Microbiol 41: 4312-4317, 2003.

31. Srisuk C, Chaivisuthangkura P, Rukpratanporn S, Longyant S, Sridulyakul P and Sithigorngul P: Rapid and sensitive detection of Vibrio cholerae by loop-mediated isothermal amplification targeted to the gene of outer membrane protein ompW. Lett Appl Microbiol 50: 36-42, 2010.
32. Diribe O, Fitzpatrick N, Sawyer J, La Ragione R and North S: A Rapid and simple loop-mediated isothermal amplification assay for the detection of Pseudomonas aeruginosa from equine genital swabs. J Equine Vet Sci 35: 929-934, 2015.

33. Pandya HJ, Kanakasabapathy MK, Verma S, Chug MK, Memic A, Gadjeva M and Shafiee H: Label-free electrical sensing of bacteria in eye wash samples: A step towards point-ofcare detection of pathogens in patients with infectious keratitis. Biosens Bioelectron 91: 32-39, 2017.

34. Jia F, Xu L, Yan W, Wu W, Yu Q, Tian X, Dai R and Li X: A magnetic relaxation switch aptasensor for the rapid detection of Pseudomonas aeruginosa using superparamagnetic nanoparticles. Microchim Acta 184: 1539-1545, 2017.

This work is licensed under a Creative Commons

Attribution-NonCommercial-NoDerivatives 4.0 International (CC BY-NC-ND 4.0) License. 